\title{
Characterization of a New Model of $\mathbf{G}_{M 2}$-Gangliosidosis (Sandhoff's Disease) in Korat Cats
}

\author{
Edward A. Neuwelt, William G. Johnson, Nathan K. Blank, Michael A. Pagel, Cheryl Maslen-McClure, \\ Michael J. McClure, and Peter Minwei Wu \\ Departments of Biochemistry, Surgery (Division of Neurosurgery), Neurology, Pathology, and Medical Genetics, \\ Oregon Health Sciences University, Portland, Oregon 97201; and Department of Neurology, \\ Columbia University College of Physicians and Surgeons, New York City 10032
}

\begin{abstract}
We have detected a disorder in Korat cats (initially imported from Thailand) that is analogous to human Sandhoff's disease. Pedigree analysis indicates that this disease in an autosomal recessive disorder in the American Korat. Postmortem studies on one affected cat showed hepatomegaly that was not reported in the only other known feline model of $G_{M 2}$-gangliosidosis type II. Histologic and ultra-structural evaluation revealed typical storage vacuoles. There was a marked deficiency in the activity of hexosaminidase (HEX) $A$ and $B$ in affected brain and liver as compared to controls. Electrophoresis of a liver extract revealed a deficiency of normal HEX $A$ and $B$ in the affected animals. The blocking primary enzyme immunoassay verified the presence of antigenically reactive HEX present in affected cat livers in quantities slightly elevated with respect to the normal HEX concentration in control cats. In leukocytes, obligate heterozygotes had intermediate levels of total HEX activity with a slight increase in the percent activity due to HEX A. Indeed, 4 of 11 phenotypically normal animals in addition to four obligate heterozygotes appear to be carriers using this assay. Affected brain and liver compared with control brain and liver contained a great excess of bound $\boldsymbol{N}$-acetylneuraminic acid in the Folch upper-phase solids; thin-layer chromatography showed a marked increase in $\mathbf{G}_{\mathbf{M 2}}$-ganglioside. In summary, we have characterized the pedigree, pathology, and biochemistry of a new feline model of $\mathbf{G}_{\mathrm{M} 2}$-gangliosidosis which is similar to but different from the only other known feline model.
\end{abstract}

\section{Introduction}

The study of lysosomal storage diseases, particularly the gangliosidoses, has been facilitated by the use of animal models. Unfortunately, well-characterized animal models are rare, and are consequently difficult to obtain for research. One of the established animal models is the feline model for human $G_{M_{2}-}$ gangliosidosis, characterized and maintained in very limited numbers (1-3). These domestic cats have a deficiency of hexosaminidase (HEX) $)^{1}$ A and B activity, the equivalent to Sandhoff's disease in humans.

Received for publication 26 December 1984 and in revised form 16 April 1985.

1. Abbreviations used in this paper: BBB, blood-brain barrier, CNS, central nervous system; HEX, hexosaminidase; HPTLC, high perfor-

J. Clin. Invest.

(c) The American Society for Clinical Investigation, Inc.

0021-9738/85/08/0482/09 \$1.00

Volume 76, August 1985, 482-490
We report here the characterization of a new feline model of Sandhoff's disease, which is similar to, yet different from the previously existing model $(1,2)$. Affected cats manifest the clinical symptoms of Sandhoff's disease including clinically apparent hepatomegaly, a finding never before reported in any animal gangliosidosis model (3). Affected animals have a marked deficiency in the activity of HEX A and B. These highly inbred Korat cats were originally imported from Thailand in 1959, and detailed genetic information is available. Carriers have intermediate levels of enzyme activity as expected with an autosomal recessive disorder.

Using the primary enzyme immunoassay (PEIA), a primary binding test which requires neither monospecific antibody nor purified enzyme, we have detected the existence of enzymatically inactive, antigenically cross-reactive $\operatorname{HEX}(4,5)$. Thus, this animal model results from a structural gene defect that is highly analogous to the human disorder (6).

\section{Methods}

Animals. The index case (see pedigree, Fig. 1) was a female Korat kitten with progressive neurologic dysfunction. The kitten was placed in our laboratory for evaluation of a suspected genetic disorder, possibly a gangliosidosis, which had been previously observed clinically by Korat breeders. A subsequent litter of kittens was bred and the litter yielded two additional affected animals, a male and a female. Other informative cats are in the custody of their owners, who have kindly provided us with blood samples and information, for which we are grateful. Normal unrelated domestic kittens of comparable age and size were obtained for controls.

Kitten 1, the index case, was killed humanely at 30 wk by barbituate overdose. Tissue biopsies from liver, brain, spleen, kidney, dorsal root ganglia, and skeletal muscle were retained and fixed for pathology. Skin samples were taken and fibroblasts were cultured and frozen for future use. Remaining tissues were frozen at $-70^{\circ} \mathrm{C}$ for subsequent enzymatic analysis. Tissues from two more affected animals have been frozen at $-70^{\circ} \mathrm{C}$ for analysis. Three unrelated normal random source kittens of comparable size and age were killed humanely by barbituate overdose, and the tissues were processed similarly to the first diseased kitten, to be used as control samples.

Pathology. The first affected kitten was anesthetized with $1 \mathrm{ml} / \mathrm{kg}$ of a ketamine/xylazine mixture $(100 \mathrm{mg} / 20 \mathrm{mg}$ per $\mathrm{ml})$ and placed on a Harvard, Model 686, small animal respirator. Biopsies of brain and liver were obtained, immediately fixed in mixed aldehydes for electron microscopy, and stained with periodic acid-Schiff (PAS) for frozen section light microscopy. After euthanasia, tissue samples, which included brain, liver, spleen, lung, skeletal muscle, sciatic nerve, dorsal root ganglia, and eye, were removed and fixed in formalin. Tissues selected for light microscopy were paraffin embedded, sectioned, and

mance thin-layer chromatographic; 4MU- $\beta$-GlcNAc, 4-methylumbelliferyl- $\beta$-D- $N$-acetyl-glucosaminide; NAN, $N$-acetylneuraminic acid; PAS, periodic acid-Schiff; PEIA, primary enzyme immunoassay. 
stained with toluidine blue, hematoxylin and eosin, PAS, and luxol fast blue. Detailed histologic evaluation was carried out at the light microscopic level.

Tissues to be examined ultrastructurally were postfixed in $2 \%$ osmium tetraoxide, dehydrated in ascending concentrations of ethanol, and embedded in Epon 812. Sections were cut with a diamond knife, mounted on bare copper grids, and stained with uranyl acetate and lead citrate.

Preparation of blood leukocyte extracts. Leukocytes were prepared from heparinized whole blood by the method of Kaback et al. (7). Erythrocytes were sedimented with dextran $\left(M_{\mathrm{r}}\right.$ of 250,000 from Sigma Chemical Co., St. Louis, MO), and the leukocyte-rich supernatant was centrifuged at $645 \mathrm{~g}$ for $5 \mathrm{~min}$ to form a leukocyte pellet. Leukocytes were resuspended in water for $30 \mathrm{~s}$ to lyse red cells, and then $\mathrm{NaCl}$ was added to a final concentration of $0.9 \%$ and the cells again centrifuged. The cells were resuspended in water and sonicated before enzyme analysis.

Preparation of tissue samples for enzyme assays. Tissue samples (brain and liver from affected and control animals) were prepared for enzyme assays by homogenization at $4^{\circ} \mathrm{C}$ in 5 vol of $0.25 \mathrm{M}$ sucrose, $5 \mathrm{mM}$ Tris, $1 \mathrm{mM}$ EDTA, pH 7.5, with $0.1 \%$ Triton X-100. Samples were then centrifuged at $4^{\circ} \mathrm{C}, 10,000 \mathrm{~g}$ for $30 \mathrm{~min}$. The supernatants were removed and retained on ice for enzyme analysis.

$\beta-H E X$ assay. Leukocytes and tissue extracts were analyzed for total $\beta$-HEX activity with $2.5 \mathrm{mM} 4$-methylumbelliferyl- $\beta$-D- $N$-acetylglucosaminide (4MU- $\beta-$ GlcNAc), from Sigma Chemical Co., as the final substrate concentration. Analysis was carried out using a modifcation of the method of Kaback et al. (8). Substrate hydrolysis was measured spectrophotometrically at $360 \mathrm{~nm}$ with a Hitachi-PerkinElmer double beam spectrophotometer and specific activity was reported as nmoles per milligram protein per hour. Percentages of total $\beta$-HEX activity due to heat labile and heat stabile fractions were determined by preincubation of the enzyme extract at $50^{\circ} \mathrm{C}$ for $2 \mathrm{~h}$.

Lysosomal enzyme assays. Brain samples were analyzed for $\beta$ galactosidase, arylsulfatase-A, and $\alpha$-L- $N$-acetylneuraminidase by methods outlined by Galjaard et al. (9). Specific activities were calculated and reported as nmoles per milligram protein per hour in all instances.

Protein determinations. The protein content of the various tissue and leukocyte samples was determined by the standard Biuret reaction for protein analysis.

Preparation of tissue samples for electrophoresis. Liver to be analyzed from a control cat for $\beta$-HEX isozymes by electrophoresis was homogenized in 5 vol of cold 25 -mM sodium phosphate buffer, pH 6. The homogenate was centrifuged at $10,000 \mathrm{~g}$ for $30 \mathrm{~min}$ at $4^{\circ} \mathrm{C}$ and the supernatant retained. Ammonium sulfate fractionation was performed with saturated ammonium sulfate, and the fraction which precipitated between 25 and $55 \%\left(\mathrm{NH}_{4}\right)_{2} \mathrm{SO}_{4}$ was collected by centrifugation at $10,000 \mathrm{~g}$ for $30 \mathrm{~min}$ at $4^{\circ} \mathrm{C}$. The precipitate was resuspended in the sodium phosphate buffer and dialyzed overnight against that buffer. The dialysate was centrifuged at $50,000 \mathrm{~g}$ for $30 \mathrm{~min}$ at $4^{\circ} \mathrm{C}$. The supernatant was retained and passed through a column $(1.5 \times 30$ cm) packed with Concanavalin A insolubilized on Sepharose that had been washed with $50 \mathrm{ml}$ of $20-\mathrm{mM}$ potassium phosphate buffer, $\mathrm{pH}$ 7.0. The $\beta$-HEX was eluted from the column in fractions with $0.2 \mathrm{M}$ $\alpha$-methyl-mannoside and fractions containing enzyme activity were pooled.

Electrophoresis. Electrophoresis of liver $\beta$-HEX isozymes was carried out on both crude enzyme $(10,000 \mathrm{~g}$ supernatant) and on a partially purified extract of control liver as prepared above. Electrophoresis of affected cat liver was only carried out with a crude homogenate due to the lack of enzyme activity, which prevented partial purification. Cellulose acetate electrophoresis was run according to Peonaru and Dreyfus with modification (10). Fluorescent staining of the bands with 4MU- $\beta$-GlcNAc substrate after electrophoretic separation was carried out according to Rattazzi et al. (11). Photographs were taken immediately after completion of the staining procedure.

Blocking PEIA. The blocking PEIA was performed as outlined by Neuwelt et al. $(4,5)$ with several modifications. This assay is analogous to a blocking radioimmunoassay, except the specificity of enzyme for substrate is used in place of a radiolabel. Aliquots of antisera were exposed to serial dilutions of blocking (test) enzyme. Antibody and/or immune complexes were precipitated after incubation by the addition of $33 \%\left(\mathrm{NH}_{4}\right)_{2} \mathrm{SO}_{4}$, and unbound enzyme was discarded. The precipitate which contained antibody and/or immune complexes was then resuspended in $\mathrm{H}_{2} \mathrm{O}$, incubated with a constant amount of standard enzyme, and reprecipitated with $33 \%\left(\mathrm{NH}_{4}\right)_{2} \mathrm{SO}_{4}$. The HEX activity remaining in the final supernatant (unbound enzyme) was then assayed. HEX activity greater than the baseline was proportional to the number of antigen binding sites blocked by test enzyme, thereby making these sites unavailable for binding to the standard enzyme.

Dissociation of bound blocking enzyme was evaluated by not adding standard enzyme to the second incubation mixture as suggested by Bell et al. (12). Standard enzyme-mediated dissociation of the blocking enzyme was evaluated by reversing the order of enzyme addition to the reaction mixtures. For comparison with this assay, immunodiffusion studies were also performed in accordance with the methods of Ouchterlony (13).

Pedigree analysis. A pedigree for the Korat cat family was constructed based on information supplied by the various breeders of the cats involved. The coefficient of inbreeding for the parents of the proband was estimated by the method originally developed by Wright (14) as outlined by Levitan and Montagu (15).

\section{Lipid analysis}

Preparation of Folch upper-phase and lower-phase lipids from brain and liver of affected and control cats. Tissues were weighed and homogenized with $19 \mathrm{vol}$ of chloroform/methanol (2:1). After suction filtration through washed filter paper, the filter cakes were rehomogenized with $10 \mathrm{vol}$ of chloroform/methanol (1:2). After filtering again, the filtrates were combined and $10 \mathrm{vol}$ of chloroform added. The modified Folch partition $(16,17)$ was performed in a separatory funnel by adding $0.2 \mathrm{vol}$ (eight original volumes) of $0.88 \%$ aqueous $\mathrm{KCl}$ solution. The funnel was shaken vigorously 200 times and let stand overnight. Phases were separated and measured, and the lower phase washed twice with theoretical-upper-phase $\mathrm{KCl}$ (chloroform/methanol/0.75\% aqueous $\mathrm{KCl}$ (2:48:47)) and once more with theoretical-upper-phase water. The upper phases were combined and solvents removed under vacuum.

The aqueous solution was dialyzed against $100 \mathrm{vol} \times 3$. of distilled water at $4^{\circ} \mathrm{C}$, centrifuged, lyophylized, and stored at $-70^{\circ} \mathrm{C}$. $N$ Acetylneuraminic acid content was determined by the method of Aminoff (18).

Sephadex G-100 was added to the lower phase to remove water (19). The filtered lower phase was taken to dryness under vacuum; absolute ethanol was added twice to dryness under the vacuum; the dry lower-phase lipids were kept at $-20^{\circ} \mathrm{C}$ and dissolved in chloroform/ methanol (1:1) for spotting on thin-layer plates.

Thin-layer chromatography. Thin-layer chromatography was performed on $20 \times 20$-cm silica gel 60 high performance thin-layer plates (A.H. Thomas Co., Philadelphia, PA) that had been activated at $110^{\circ} \mathrm{C}$ for $1 \mathrm{~h}$. The concentration zone on these plates was not used; plates were run with this zone at the top, having been spotted $2 \mathrm{~cm}$ up from the lower margin. Upper-phase solids were spotted from water, lower phase from chloroform/methanol (1:1). Plates were developed (20) ascending (in chambers equilibrated with blotting paper) to $18 \mathrm{~cm}$ from the bottom. Plates of lower-phase lipids were sprayed with orcinol to detect carbohydrate-containing spots and (on separate plates) with resorcinol spray reagents to identify bands containing sialic acid (19).

\section{Results}

Clinical presentation. Korat cats affected with Sandhoff's disease were discovered through recognition of their clinical symptoms. The affected animals exhibited a progressive neurologic dysfunction that was first recognizable between 4 and 7 wk of 
age. A fine head tremor was first noted, which was sometimes accompanied by excess tearing of the eyes. The animals rapidly became ataxic, and mobility was lost by $8-10$ wk. Spasticity and loss of vision developed concurrently, and dysphagia has also been noted. Seizures, or generalized myoclonus, began occurring at $\sim 5 \mathrm{mo}$, becoming progressively more frequent and severe. Response to auditory stimulus remained acute, but there was no abnormal startle reflex as seen in affected humans. Spastic quadraplegia occurred by $6 \mathrm{mo}$, with death before $8 \mathrm{mo}$.

Pedigree analysis. The pedigree constructed for the Korat cat family under investigation is consistent with an autosomal recessive mode of inheritance for $\mathrm{G}_{\mathrm{M} 2}$-gangliosidosis (Fig. 1). Evidence which supports this hypothesis is that both sexes are affected, parents are phenotypically normal, siblings are frequently affected, there is parental consanguinity, and there is disease recurrence in the inbred population after many skipped generations.

An estimate of the coefficient of inbreeding $(F)$ for the parents of the proband concluded that these individuals have $\sim 59 \%$ of their genes in common, which indicated that they are genetically more closely related than full siblings.

Pathology. Postmortem examination of various tissues from the initial 7-mo-old affected kitten displayed the histopathologic consequences of advanced $\beta$-HEX deficiency. Histologic and ultrastructural evaluation revealed cytoplasmic storage vacuoles typical of neuronal lipidosis. Evidence of lysosomal hypertrophy in the form of diffuse vacuolation was apparent in neurons, hepatocytes, macrophages, and bone marrow, as well as in other cell types. Numerous membranebound inclusion bodies were detected by transmission electron microscopy in the heavily vacuolated cells.

The liver from the affected kitten was grossly enlarged and had the appearance of a fatty liver. It weighed $75 \mathrm{~g}$, as compared with 45-50 g each for three livers from normal cats of similar size. As demonstrated in Fig. 2, most of the hepatocytes and Kupffer cells contained a single large cytoplasmic vacuole, which was at times both PAS-positive in paraffin sections and positive for lipid in frozen sections. Some cells contained hematoxylin-positive granules that were occasionally associated with small clear cytoplasmic vacuoles. Transmission electron microscopy revealed that most of the vacuoles were filled with lightly osmophilic staining, fluffy material that was interspersed with small concentric laminated membranous bodies (Fig. 3). The inclusions were quite dissimilar from those observed in neural tissue.

The brain, dorsal root ganglia, and retinal ganglion cells contained large distended neurons with dispersed Nissl bodies and vacuolation. The inclusions were PAS-positive and on ultrastructural analysis were composed of highly pleomorphic multilaminated membranes. Detailed descriptions of the histopathology from the affected kitten will be reported separately.

Enzyme analysis for $\beta$-HEX. Total $\beta$-HEX (HEX A + B) levels, expressed in nanomoles of $4 \mathrm{MU}$ released per milligram protein per hour, were significantly decreased over control values in the leukocytes, liver, and brain from the affected animals (Table I). There was no detectable activity in brain tissue from kitten 1, which was 3 mo older and more severely

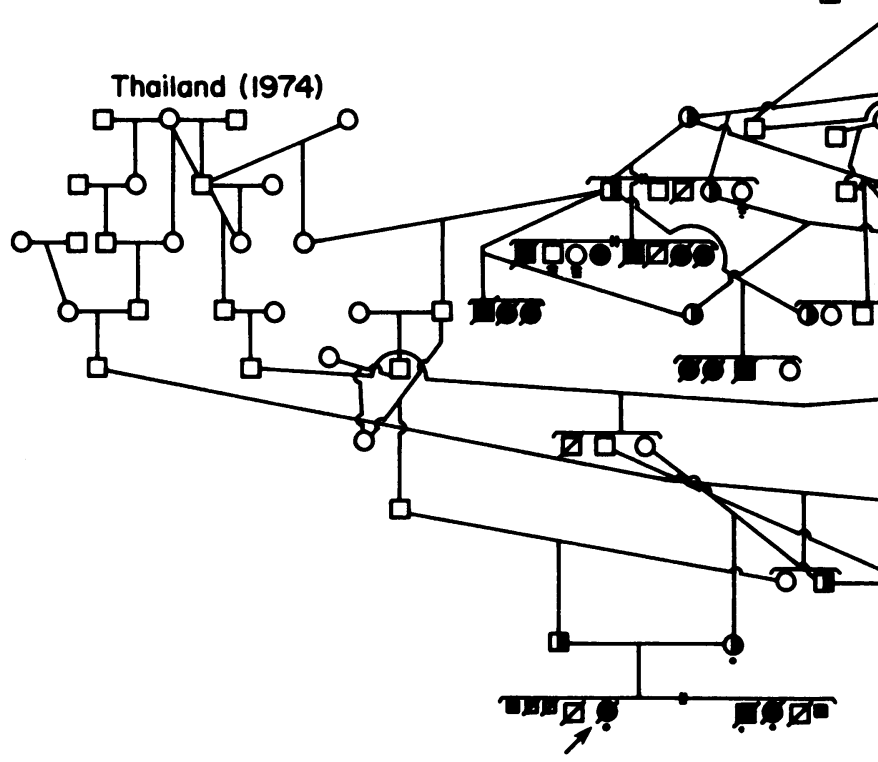

Pigure 1. Pedigree of Korat cat family dating to the initial importation of Korats into the United States in 1959. The pedigree is consistent with an autosomal recessive mode of inheritance of $G_{M 2}$ gangliosidosis type II. Arrow indicates proband (cat 1 ). Kittens re- ported in this study are the three affected animals in the most recent generation. $\phi f$, Affected by history, deceased; on, obligate heterozygote; $\varphi$, confirmed heterozygote; $\phi$, , confirmed affected, deceased; $O \square$, status unknown. 


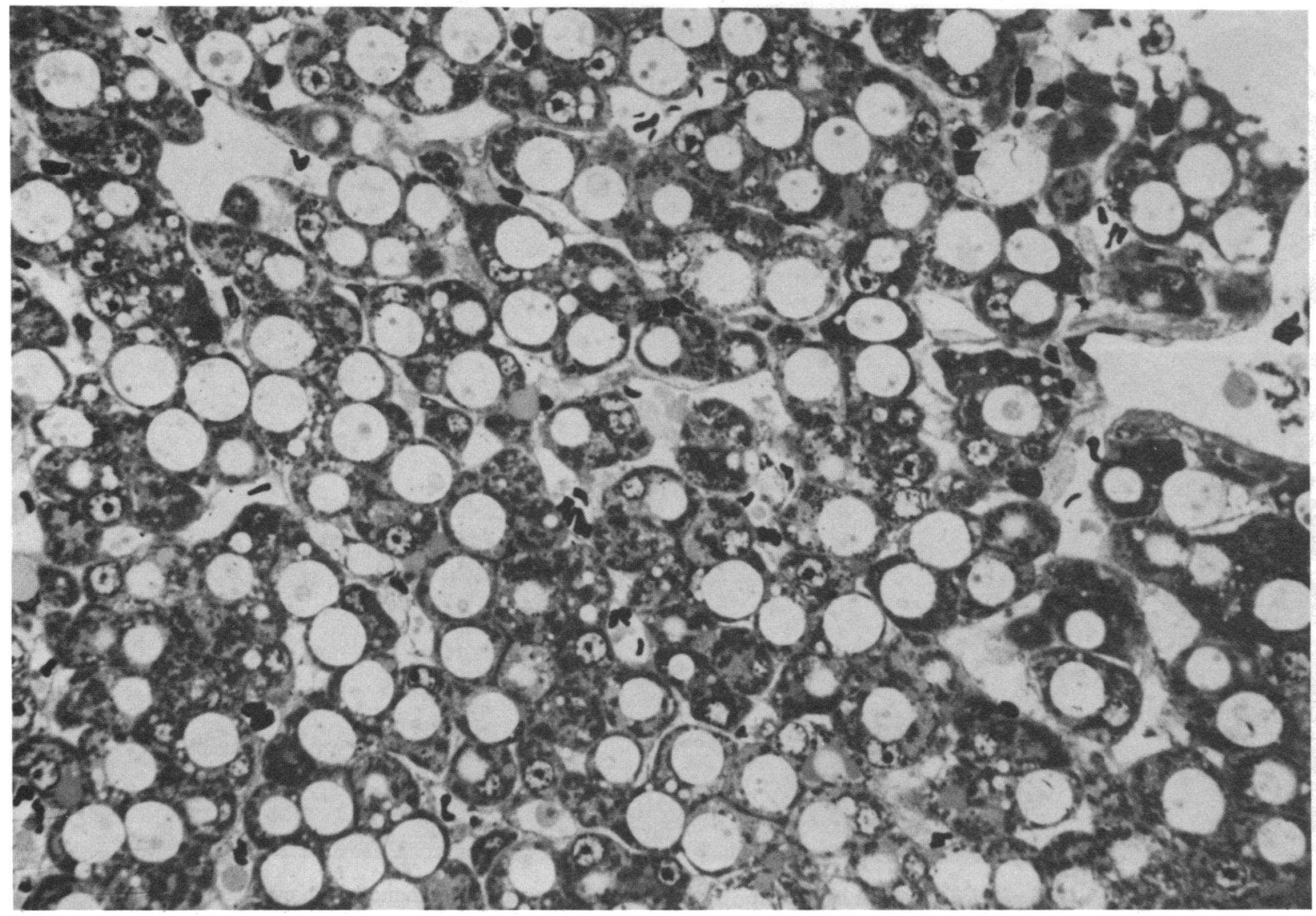

Figure 2. Histopathologic section of affected cat liver demonstrates single large intracytoplasmic vacuoles in hepatocytes and Kupffer cells (hematoxylin and eosin $\times 612$ ).

affected than kitten 2 , which had $14 \%$ of normal activity. Affected liver, which normally expresses a high level of HEX activity, had from 4 to $6 \%$ of the activity seen in the normal controls. The small amount of residual activity seen may be due to HEX S, a HEX alpha subunit homopolymer seen in human Sandhoff fibroblasts as reported by Proia et al. (21), or HEX C, an unrelated enzyme.

Characterizations of the PEIA. The experimental and control curves for the PEIA are shown in Fig. 4. Experimental curves $\mathrm{A}$ and $\mathrm{C}$, which correspond to control cat and human enzyme, respectively, did not produce the expected upper plateau region at high concentrations of the blocking enzyme, indicating the dissociation of some of the blocking enzyme bound in the first incubation from its immune complex into the final incubation mixture. Control curves $B$ and $D$ represented the evaluation of this possibility by the addition of buffer to the second incubation rather than the standard enzyme mixture. In this situation, any activity remaining in the final supernatant must have been due to blocking enzyme activity. The control lines $B$ and $D$ could then be subtracted from the experimental lines A and C, respectively, to present an approximate true value blocking curve.

One explanation for the reduced activity in the supernatant for the affected cat liver assay (line E) was reduced binding of the affected cat enzyme by antibody. An alternative explanation for this decreased supernatant HEX activity curve with affected cat liver enzyme other than reduced binding has been proposed. The possibility exists that free standard enzyme in the final reaction mixture is in rapid equilibrium with the bound blocking enzyme, thereby inducing the release of the blocking enzyme from antibody. With enzymatically active enzyme, this possibility was inconsequential due to the fact that a onefor-one exchange of active standard enzyme for active blocking enzyme would have no net effect. However, when the blocking enzyme has no enzymatic activity, this possibility takes on more significance. To evaluate this possibility, curve $F$ was derived by reversing the order of the assay by adding the standard (normal human) enzyme to the first incubation mixture, and the blocking enzyme from a Sandhoff animal to the second incubation mixture. Had this alternative explanation been true, the expectation would have been release of a significant amount of active (human) enzyme into the supernatant. This did not occur. As a result of this control, it was concluded that it is the reduced binding of the affected cat enzyme protein that is responsible for this reduced curve (line E, Fig. 4).

The PEIA was also able to reveal quantitative results about the test enzymes, even though those enzymes may not be subject to direct assays, such as in the case of an inactive enzyme. Since the midpoints between the plateaus of each curve represented the quantity of blocking enzyme that occupies $50 \%$ of its antigen binding sites, the relative enzyme protein of each blocking solution could be evaluated by drawing a perpendicular line from this point to the relative enzyme protein axis (dotted lines, Fig. 4).

Results of the PEIA. A reaction of identity may be defined 


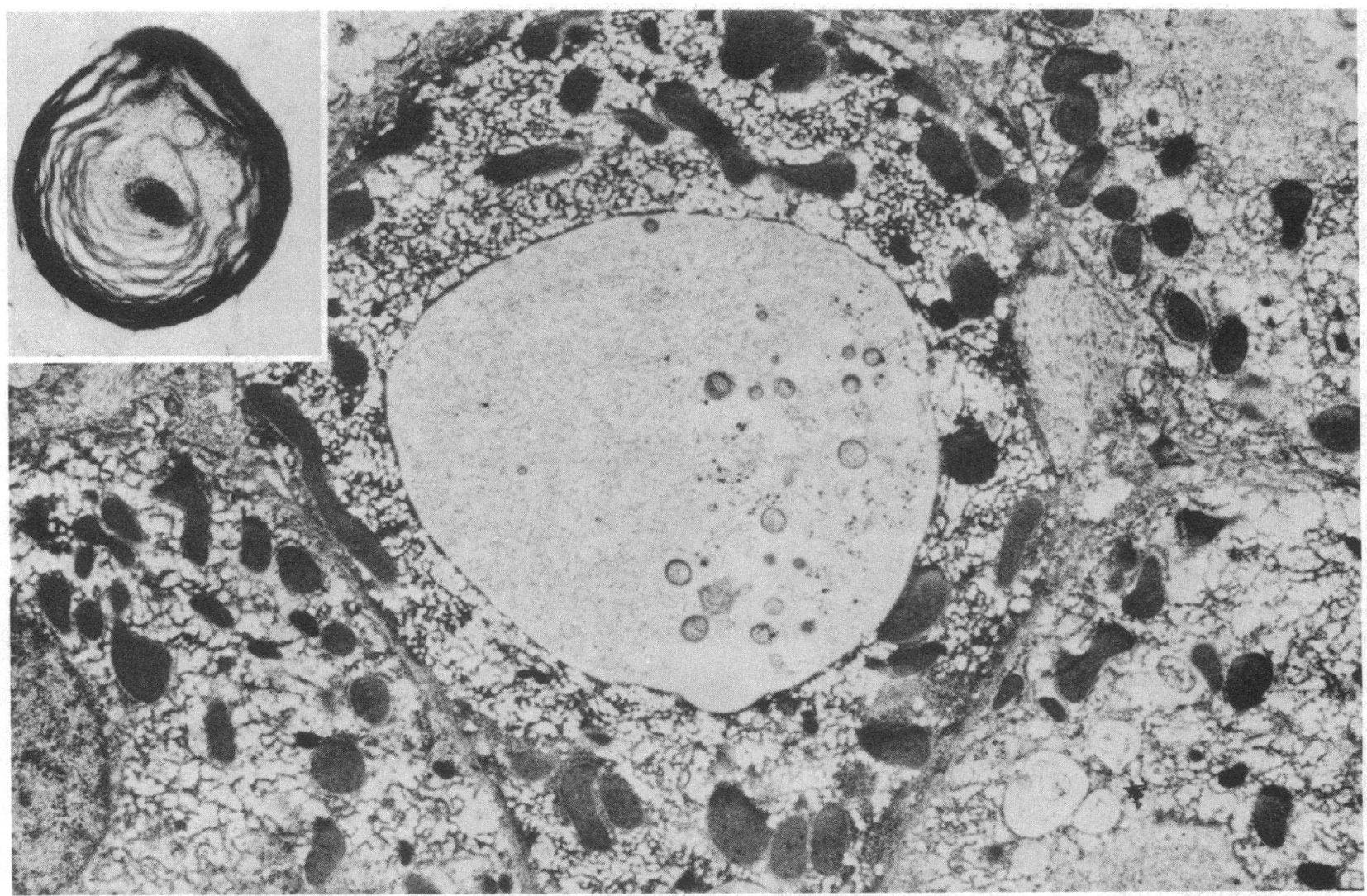

Figure 3. Electron micrograph of a large vacuole with a hepatocyte from affected cat liver. $\times 7,100$. The inset at the upper left depicts a small concentric laminated membranous body that is representative of inclusions occasionally found within cytoplasmic vacuoles. $\times 13,600$. as the binding that an antibody has against the antigen against which it was created. By definition, therefore, line A minus B could be characterized as the reaction of identity for this system, as the blocking enzyme in this curve is the purified human placental HEX against which the antibody was prepared. Interestingly, crude control cat liver enzyme was found to be nearly identical in its binding (line $\mathrm{C}$ minus D). Affected cat liver crude enzyme was able to block a reduced quantity of antigenic sites (line $\mathrm{E}$ ), and is therefore a reaction of partial identity. The PEIA also revealed the quantitative finding that enzymatically inactive affected cat HEX enzyme protein was present in quantities $\sim 23 \%$ greater than control cat enzyme. However, immunodiffusion studies with Ouchterlony plates (data not shown) using control and affected cat liver enzyme were unable to demonstrate any precipitin lines against the anti-human HEX A rabbit antisera. As expected, using an

Table I. $\beta$-HEX Activity in Tissues of Normal Cats, Korat Cats with $G_{M z}-$ Gangliosidosis Type II, and Carriers of $G_{M 2}$-Gangliosidosis Type II

\begin{tabular}{|c|c|c|c|c|c|c|c|c|c|c|c|c|}
\hline \multirow[b]{3}{*}{ Source } & \multicolumn{12}{|c|}{$\beta$-HEX levels* } \\
\hline & \multicolumn{4}{|l|}{ Brain } & \multicolumn{4}{|l|}{ Liver } & \multicolumn{4}{|c|}{ Leukocytes } \\
\hline & $\begin{array}{l}\text { Total } \\
\text { specific } \\
\text { activity }\end{array}$ & HEX A & HEX B & \% HEX A & $\begin{array}{l}\text { Total } \\
\text { specific } \\
\text { activity }\end{array}$ & HEX A & HEX B & \% HEX A & $\begin{array}{l}\text { Total } \\
\text { specific } \\
\text { activity }\end{array}$ & HEX A & HEX B & \% HEX A \\
\hline Normal cats & 2,602 & 1,613 & 989 & 62 & 7,916 & 4,691 & 3,158 & 59 & 1,739 & 1,250 & 264 & 83 \\
\hline \multicolumn{13}{|l|}{ Affected cats } \\
\hline Kitten 1 & ND & ND & ND & ND & 332 & 222 & 109 & 67 & ND & ND & ND & ND \\
\hline Kitten 2 & 365 & 261 & 104 & 72 & 469 & 348 & 121 & 74 & - & - & - & - \\
\hline \multicolumn{13}{|c|}{ Obligate carrier } \\
\hline Mother & - & - & - & - & - & - & - & - & 279 & 253 & 27 & 91 \\
\hline
\end{tabular}

* Mean activity is expressed as nanomoles per milligram protein per hour (2-4 determinations). ND, no detectable activity. - no sample available. 


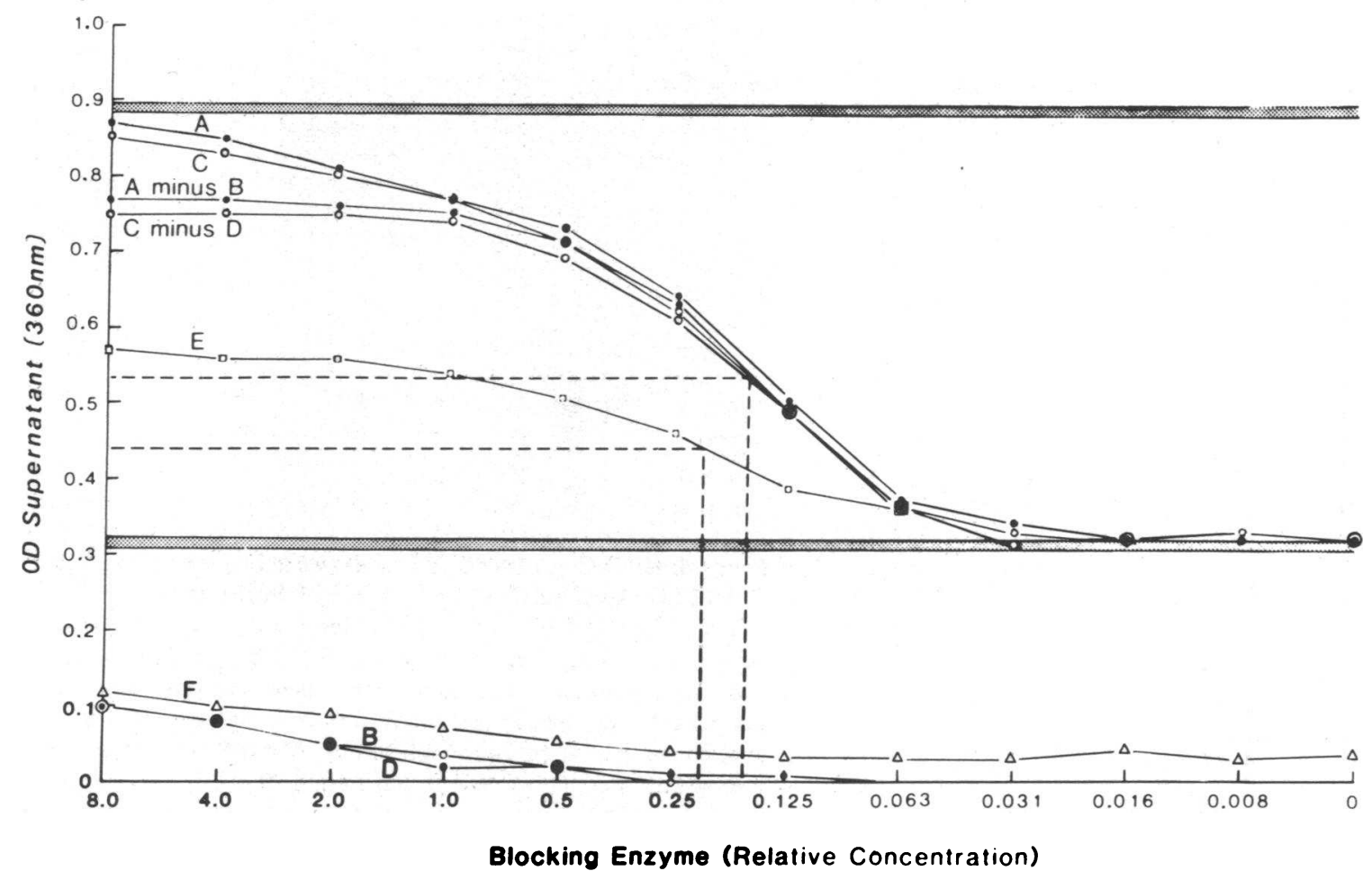

Figure 4. Use of the PEIA to compare the antigenicity of affected cat liver HEX (curve E) with control cat liver and human placental enzyme (curves $C$ minus $D$ and $A$ minus $B$, respectively). Curves $A$ minus $B$ and $C$ minus $D$ are the experimental blocking curves, and $A$ and $C$ are corrected for blocking enzyme-antibody dissociation quantitated in curves $B$ and $D$, respectively. Curve $F$ is an additional control discussed in the text. The dashed lines correspond to the point at which $50 \%$ of the blocking enzyme is bound to antibody and was used to quantify the relative amounts of blocking enzyme pres-

equivalent amount of crude human placental enzyme and crude human liver enzyme, a precipitin line did develop.

Determination of carrier state. 18 Korat cats were evaluated for HEX activities in leukocytes in an attempt to determine carrier status. Four normal domestic cats had leukocyte enzyme levels of $1,739 \pm 197$ (SD) $\mathrm{nmol} / \mathrm{mg}$ protein per $\mathrm{h}$ (Fig. 5). Seven Korats, which were presumed to be normal, had an average total hex activity of $741 \pm 170 \mathrm{nmol} / \mathrm{mg}$ protein per $\mathrm{h}$, which was $43 \%$ of domestic cat levels. Four obligate heterozygotes had enzyme activities of $361 \pm 56 \mathrm{nmol} / \mathrm{mg}$ protein per h. These levels were 21 and $49 \%$ of domestic and normal Korat cat HEX levels, respectively. Another four Korats evaluated had levels of $227 \pm 171 \mathrm{nmol} / \mathrm{mg}$ protein per $\mathrm{h}$, and were presumed to be carriers of the condition. Affected animals $(n=3)$ had no detectable activities.

$\beta-H E X$ isoenzymes in normal and affected cat tissues. Electrophoresis of the enzymes from crude homogenates of normal cat liver followed by $\beta$-HEX-specific staining showed two brightly fluorescing bands of $\beta$-HEX activity (data not shown). The bands were very distinct if partially purified normal cat liver HEX was used rather than crude cat liver extract. If the normal cat liver extract (partially purified) was heated before electrophoresis and staining, one of the two $\beta$-HEX bands was no longer seen. By analogy with human HEX isoenzymes, the heat-labile band in the cat liver extracts was designated HEX A and the heat-stabile band HEX B.

After electrophoresis and staining of crude liver homoge- ent. The standard enzyme was assigned a relative protein concentration of 1.0. (A) Human placental hex as a blocking enzyme + standard enzyme; $(B)$ human placental hex as blocking enzyme + buffer; $(C)$ control cat liver hex as blocking enzyme + standard enzyme; $(D)$ control cat liver hex as blocking enzyme + buffer; $(E)$ affected cat liver hex as blocking enzyme + standard enzyme; $(F)$ human placental hex as blocking enzyme + affected cat liver.

nates from the affected cat (kitten 1), neither band, HEX A or HEX B, was present. With maximal enzyme loading, no evidence of a third band corresponding to the human HEX $S$ was seen either in affected or unaffected cat tissue extracts.

Other lysosomal enzymes. An increase in the activity of lysosomal enzymes other than the defective enzyme is a feature frequently seen in lysosomal storage disease; however, it was not as clear cut in this animal model. One affected animal displayed an elevation in brain levels of $\beta$-galactosidase and arylsulfatase-A as compared to controls. No difference from controls was seen in $\alpha$-L- $N$-acetylneuraminidase activities from either of the affected animals.

Identification of the stored materials. Identification of the brain and liver storage material was of particular interest, as these tissues showed the most dramatic evidence of storage abnormalities. Bound $N$-acetylneuraminic acid (NAN) content expressed in nanomoles NAN per milligram tissue wet weight was 9.1-fold (cat 1) and 3.7-fold (cat 2) increased in brain upper-phase solids of the affected cats compared with the control cat (Table II). High performance thin-layer chromatographic (HPTLC) analysis of the upper-phase solids (Fig. 6) showed a striking increase of $\mathrm{G}_{\mathrm{M2} \text {-ganglioside. In liver, bound }}$ NAN content was 6.6-fold (cat 1) and 3.9-fold (cat 2) increased in upper-phase solids of the affected cats compared with control cat (Table II). By HPTLC, this increase was accounted for in both brain and liver by strikingly increased $\mathbf{G}_{\mathbf{M 2}^{-}}$ ganglioside. However, gangliosides as yet unidentified, most 


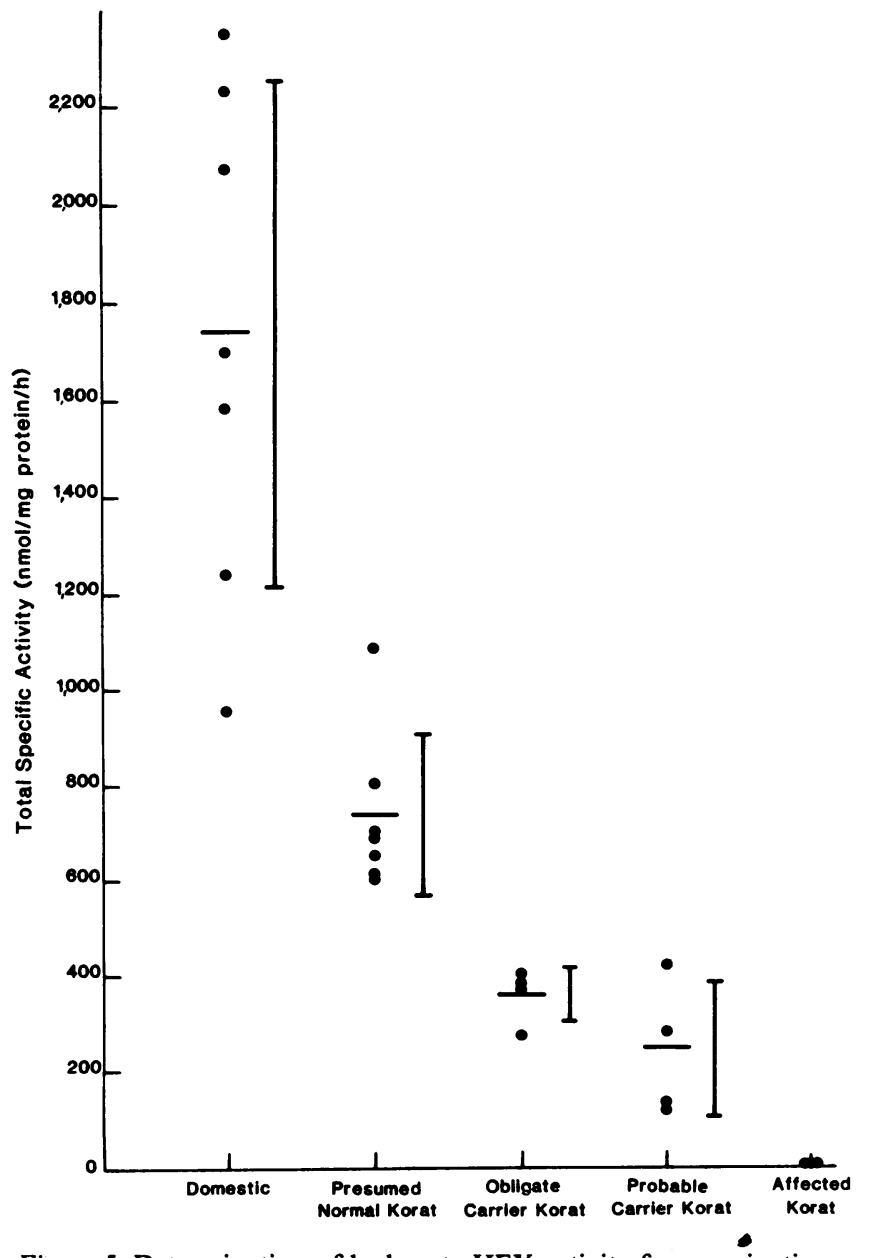

Figure 5. Determination of leukocyte HEX activity for examination of the carrier state. Domestic $(n=4)$ and Korat $(n=18)$ cats were evaluated for total HEX activity. Leukocytes were suspended and sonicated in water for analysis after centrifugation (645 $g$ for $5 \mathrm{~min}$ ) from separated whole blood with dextran. Activity is expressed as nanomoles substrate cleaved per milligrams protein per hour. All groups except obligate and probable carrier Korats were significantly different $(P<0.005)$.

with mobilities between those of $\mathrm{G}_{\mathrm{M} 1^{-}}$and $\mathrm{G}_{\mathrm{M} 2}$-gangliosides, were also strikingly increased in liver of the affected cat compared with the normal. These unidentified gangliosides were not seen in normal or abnormal cat brain or normal human brain (Fig. 7). Presumably these unidentified ganglio-

Table II. Bound Sialic Acid Content of Folch Upper-Phase Solids*

\begin{tabular}{|c|c|c|}
\hline & & Upper phase \\
\hline & & nmol NAN/g tissue \\
\hline \multirow[t]{3}{*}{ Brain: } & Normal cat & 441 \\
\hline & Affected cat 1 & 4,020 \\
\hline & Affected cat 2 & 1,640 \\
\hline \multirow[t]{3}{*}{ Liver: } & Normal cat & 83.6 \\
\hline & Affected cat 1 & 555 \\
\hline & Affected cat 2 & 326 \\
\hline
\end{tabular}

\footnotetext{
* Mean sialic acid content is expressed as nanomoles NAN per gram
} of tissue wet weight.

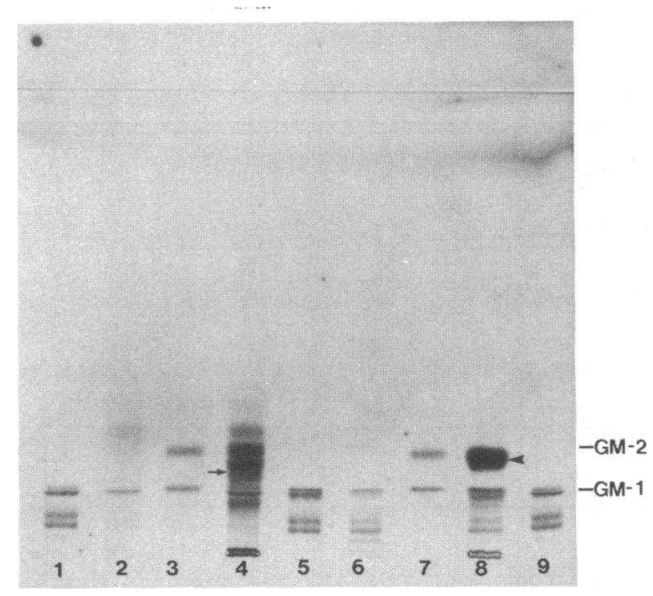

Figure 6. HPTLC of upper-phase solids (resorcinol spray). Silica gel 60 HPTLC plate; mobile phase (13) chloroform/methanol/1 N aqueous $\mathrm{NH}_{4} \mathrm{OH} / 60: 35: 8$. Lanes 1, 5, and 9: mixed human brain gangliosides $(25 \mu \mathrm{g})$; lanes 3 and 7 : mixed $\mathrm{G}_{M 1}$-ganglioside $(10 \mu \mathrm{g})$ and $\mathrm{G}_{\mathrm{M} 2}$-ganglioside (5 $\mu \mathrm{g}$ ) (Supelco Inc., Bellefonte, PA); lane 2: normal cat liver, upper-phase solids from $20.0 \mathrm{mg}$ tissue; lane 4: affected cat liver, upper-phase solids from $20.4 \mathrm{mg}$ tissue; lane 6: normal cat brain, upper-phase solids from $5.79 \mathrm{mg}$ tissue; lane 8 : affected cat brain, upper-phase solids from $5.78 \mathrm{mg}$ tissue. The arrow indicates unidentified liver gangliosides with mobilities between $\mathrm{G}_{\mathrm{MI}^{-}}$ and $G_{M 2}$-gangliosides. The arrowhead (lane 8 ) indicates increased levels of $G_{M 2}$-ganglioside in affected cat brain. Migration of $G_{M 1}$ and $\mathrm{G}_{\mathrm{M} 2}$ standards are indicated along margin.

sides contain terminal beta linked $\mathrm{N}$-acetylated galactosamine or glucosamine as is the case (22) with the minor gangliosides $\mathrm{G}_{\mathrm{Dla}}-\mathrm{GalNAc}\left(\mathrm{IV}^{4} \mathrm{GalNAc}, \mathrm{IV}^{3} \mathrm{NeuAc}, \mathrm{II}^{3} \mathrm{NeuAc}-\mathrm{GgOse}{ }_{4} \mathrm{Cer}\right)$ and $\mathrm{G}_{\mathrm{M} 1 \mathrm{~b}}-\mathrm{GalNAc}\left(\mathrm{IV}^{4} \mathrm{GalNAc}, \mathrm{IV}^{3} \mathrm{NeuAc}-\mathrm{GgOse}{ }_{4} \mathrm{Cer}\right.$ ).

Lower-phase lipids were also abnormal (Fig. 7). Cat brain contained a single orcinol-positive species, migrating as GL-3, present in striking excess in affected brain compared with normal brain and presumed to be gangliotriaosylceramide. In the liver of the affected cat compared with control liver, a similar but smaller excess of presumed gangliotriaosylceramide was found. However, a striking and much greater excess was found of an orcinol-positive lipid, which migrated with globotetraosylceramide and was presumed to be globotetraosylceramide. The small amount of orcinol-positive and resorcinolpositive material near the origin found in both affected brain and liver but not control brain and liver appeared to be unextracted $\mathrm{G}_{\mathrm{M} 2 \text {-ganglioside. }}$

Strikingly increased brain $\mathrm{G}_{\mathrm{M} 2 \text {-ganglioside and ganglio- }}$ triaosylceramide with increases in liver of globotetraosylceramide and to a lesser extent gangliotriaosylceramide were findings quite compatible with Sandhoff disease in humans. The unusual feature in the affected cats was the additional presence in liver of large amounts of unidentified gangliosides, which may be a special feature of this feline model.

A large excess of at least two abnormal oligosaccharides was found by HPTLC (23) in water extracts of affected cat liver, spleen, kidney, and heart; these were not seen in water extracts of control cat liver (data not shown).

\section{Discussion}

The usefulness of animal models of the $G_{M 2}$-gangliosidoses is well recognized. Confirmed lysosomal storage diseases involving 


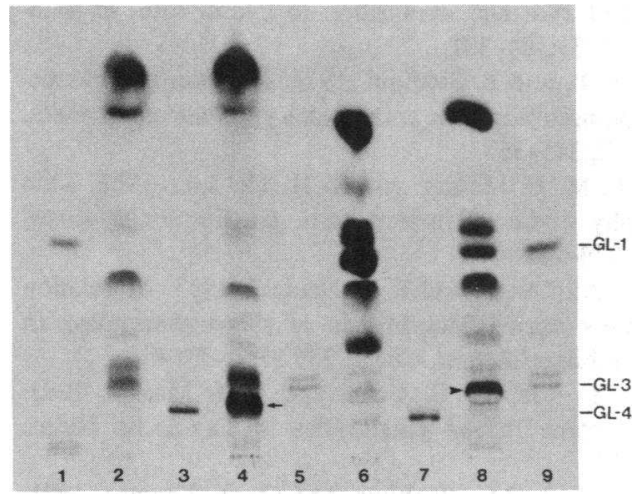

Figure 7. HPTLC of lower-phase solids (orcinol spray). Silica gel 60 HPTLC plates; mobile phase chloroform/methanol/water/65:25:4. Lane 1: Mixture of bovine brain cerebrosides (GL-1) type IV (Sigma Chemical Co., band half way up lane 1 and 9 ), $\mathrm{G}_{\mathrm{M} 1 \text {-ganglioside }}$

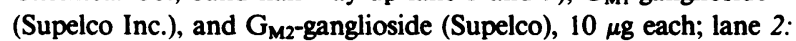
normal cat liver, lower-phase solids from $17.5 \mathrm{mg}$ tissue; lane 3: GL-4 (globotetraosylceramide) (Supelco Inc.) $(10 \mu \mathrm{g})$; lane 4: affected cat liver, lower-phase solids from $17.5 \mathrm{mg}$ tissue; lane 5: GL-3 (globotriaosylceramide) (Supelco Inc.), (20 $\mu \mathrm{g})$; lane 6: normal cat brain, lower-phase solids from $11.2 \mathrm{mg}$ tissue; lane 7: same as lane 3; lane 8: affected cat brain, lower-phase solids from $11.2 \mathrm{mg}$ tissue; lane 9: mixture of cerebrosides (10 $\mu \mathrm{g}$ as in lane 1) and GL-3 $(20 \mu \mathrm{g}$, as in lane 5). Lane 4 indicates increased levels of a GL-4 (arrow), which were presumed to be globotetraosylceramide because of similar migration of GL-4 standard as seen in lane 3. Also, increased levels of GL-3 in lane 8 (arrowhead) migrated in the same manner as GL-3 standard in lane 9. Migration of GL-1, GL-3, and GL-4 standards are indicated at their leading edges along margin, note that standards appear as doublets.

$\mathrm{G}_{\mathrm{M} 2}$-ganglioside have been reported in domestic cats, dogs, and swine (2). However, only one of these models has been maintained for research purposes. A feline model of $\mathrm{G}_{\mathbf{M 2}^{-}}$ gangliosidosis type II is currently being investigated by Rattazzi et al. (24) for exogenous enzyme replacement. The discovery of $\mathrm{G}_{\mathrm{M} 2}$-gangliosidosis type II in a Korat cat family has resulted in the development of a new model for the human disorder. The Korat cat model is similar to the other known feline model of $\mathrm{G}_{\mathrm{M} 2}$-gangliosidosis type II, but with significant differences. The occurrence of clinically apparent hepatomegaly in the Korat cat, unlike the model reported by Rattazzi et al. (24), is often reported in the human condition. The characterization of antigenically cross-reactive material is significant in that it makes the model analogous to the human condition. Not only is the genetic defect determined to be a structural gene defect as in the human condition, but in addition, the presence of cross-reactive gene products may minimize the immune response after possible enzyme replacement therapy.

The PEIA has been used in this study to characterize the inactive affected cat enzyme protein. The advantages of this assay are its specificity and the fact that it eliminates the necessity of the monospecific antibody and/or pure antigen required for most immunoassays. Indeed, the only requirement for this system is the availability of a substrate that is specific for the activity of the standard enzyme. The PEIA is highly sensitive in its ability to differentiate mutant enzymes from the same species $(4,5)$. In this study, immunodiffusion studies on Ouchterlony plates were unable to reveal the existence of any cross-reactive material from either normal or affected cat liver, let alone differentiate between the normal and mutant cat enzyme, even though normal human placental and liver HEX A resulted in very definite precipitin lines which formed a line of identity.

We were also able to demonstrate a distinct separation between normal Korats and obligate heterozygotes. These findings concur with other feline models such as the $G_{M 1}$ model reported by Baker (3) and $G_{M 2}$-gangliosidosis model by Cork (1). Breeding among the suspected heterozygotes will indicate whether or not we can successfully identify carriers of the disorder and predict matings which will result in affected offspring.

The discovery and characterization of this model affords the opportunity to investigate the pathogenesis of lysosomal storage diseases, and to examine the efficacy of potential therapeutic trials, in particular the approaches to enzyme replacement therapy, or gene therapy. Numerous investigators have demonstrated that intravenous administration of active $\beta$-HEX A clears stored gangliosides from the serum and is taken up by the liver in patients with Tay-Sachs disease $\left(\mathrm{G}_{\mathrm{M2}^{-}}\right.$ gangliosidosis type I) (25). Intrathecal injections of enzyme result in similar clearance of serum gangliosides (26). No clinical trials, however, have been successful at transporting active enzyme across the blood-brain barrier (BBB) to the central nervous system (CNS), where its activity is most critical. Consequently, there is no clinical improvement in patients who have received therapeutic enzyme.

Several approaches to reversible opening of the BBB have been established with varying degrees of success. Osmotic BBB disruption has proven to be one of the safest and most useful methods of reversible BBB modification to date (27). It is successfully used in clinical chemotherapeutic trials for malignancies of the CNS (28) and is being evaluated for use in the treatment of CNS infections (29). It has been demonstrated in rats that active HEX $A$ can be delivered to the cerebrum after osmotic disruption of the BBB, and that the enzyme is taken up by subcellular organelles presumed to be lysosomes ( 30 , 31). Uptake of HEX by brain cells may be a receptor-mediated event, which suggests that the process could be facilitated if the enzyme is recognized by the receptor (32-34). The potential for amelioration of stored substrate in the CNS is supported by studies that have shown degradation of accumulated substrate in systemic organs after intravenous enzyme infusion in another feline model of $\mathrm{G}_{\mathrm{M2}}$-gangliosidosis (24). These studies indicate a potential for beneficial enzyme replacement therapy in conditions that require enzyme delivery to the CNS. The model reported here could be used to evaluate such therapy.

\section{Addendum}

Since this manuscript was submitted, O'Dowd et al. (35) have reported the isolation of cDNA clones coding for the $\beta$ subunit of human $\beta$ hexosaminidase. The availability of this information makes the possibility of substituting the functional human gene for the defective cat gene in this model of $\mathrm{G}_{\mathrm{M} 2}$ gangliosidosis.

\section{Acknowledgments}

Drs. Neuwelt, Blank, Pagel, C. Maslen-McClure, and M. McClure were supported by the Veterans Administration, U. S. Public Health Service grant CA31770, the Oregon Medical Research Foundation, the John Raaf Institute, and The National Science Foundation, as well as by a grant from the National Institutes of Health (R01-NS-15281). Dr. 
Johnson and Dr. Wu were supported by the Muscular Dystrophy Association of America (H. Houston Merritt Clinical Center for Muscular Dystrophy and Related Diseases), The March of Dimes Birth Defects Foundation, and The Alexander Rapoport Foundation.

\section{References}

1. Cork, L. C., J. F. Munnell, M. D. Lorenz, J. V. Murphy, H. J. Baker, and M. C. Rattazzi. 1977. $\mathrm{G}_{\mathrm{M} 2}$ ganglioside lysosomal storage disease in cats with $\beta$-hexosaminidase deficiency. Science (Wash. DC). 196:1014-1017.

2. Baker, H. J., G. D. Reynolds, S. U. Walkley, N. R. Cox, and G. H. Baker. 1979. The gangliosidoses: comparative features and research applications. Vet. Pathol. 16:635-646.

3. Baker, M. J., J. A. Mole, R. Lindsey, and R. N. Creol. 1976. Animal models of human ganglioside storage diseases. Fed. Proc. 35(5):1193-1201.

4. Neuwelt, E., P. F. Kohler, and J. Austin. 1973. Methodology primary enzyme immunoassay (PEIA): studies of the mutant enzyme in metachromatic leukodystrophy (primary enzyme immunoassay of arylsulfatase-A). Immunochemistry. 10:767-773.

5. Neuwelt, E. A. 1981. Use of antibodies and the primary enzyme immunoassay (PEIA) to study enzymes: the arylsulfutase A-antiarylsulfatase A system. Methods Enzymol. 73:550-578.

6. Srivistava, S. K., and E. Beutler. 1974. Studies on human $\beta$-DN-Acetylhexosaminidases. J. Biol. Chem. 249(7):2054-2057.

7. Kaback, M. M., L. J. Shapiro, P. Hirsch, and C. Roy. Appendix A. 1977. In Tay-Sachs Disease: Screening and Prevention. M. M. Kaback, editor. Alan R. Liss, Inc., NY. 276-279.

8. Kaback, M. M., and J. S. O'Brien. 1977. Tay-Sachs disease heterozygote detection: a quality control study. In Tay-Sachs Disease: Screening and Prevention. M. M. Kaback, editor. Alan R. Liss, Inc., NY. 267-279.

9. Galjaard, H. 1980. Genetic metabolic diseases. Early diagnosis and prenatal analysis. Elsevier/North-Holland Biomedical Press, Amsterdam. 825.

10. Poenaru, L., and J. C. Dreyfus. 1973. Electrophoretic study of hexosaminidases. Hexosaminidase C. Clin. Chim. Acta. 43:439-442.

11. Rattazzi, M. D., P. J. Carmody, and R. G. Davidson. 1975. Studies on human lysosomal $\beta$-D- $N$-acetyl-hexosaminidase and arylsulfatase isozymes. In Isozymes II. Physiological Function, C. L. Markert, editor. Academic Press, Inc., NY. 440-442.

12. Bell, C. E., W. S. Sly, and F. E. Brot. 1977. Human $\beta$ glucuronidase deficiency mucopolysaccharidosis. J. Clin. Invest. 59: 97-105.

13. Ouchterlony, O. 1949. Antigen-antibody reactions in gels. Acta Pathol. Microbiol. Scand. 26:507-515.

14. Wright, S. 1922. Coefficients of inbreeding and relationships. Am. Nat. 56:330-338.

15. Levitan, M., and A. Montagu. 1977. Consanguinity and genetic inference. In Textbook of Human Genetics. Oxford University Press, NY. Second ed. 482.

16. Folch, J., M. Lees, and G. H. S. Stanley. 1957. A sample method for the isolation and purification of total lipids from animal tissues. J. Biol. Chem. 226:497-509.

17. Suzuki, K. 1965. The pattern of mammalian brain gangliosides-II. Evaluation of the extraction procedures, post-mortem changes and the effect of formalin preservation. J. Neurochem. 12:629-638.

18. Aminoff, D. 1961. Methods for quantitative estimation of $\mathrm{N}$ - acetylneuraminic acid and their application to hydrolysates of sialomucoids. Biochem. J. 81:384-391.

19. Hakomori, S. I., and B. Siddiqui. 1974. Isolation and characterization of glycosphingolipids from animal cells and their membranes. Methods Enzymol. 32:345-367.

20. Penick, R. J., M. H. Meisler, and R. H. McCluer. 1966. Thin layer chromatography studies of human brain gangliosides. Biochim. Biophys. Acta. 116:279-287.

21. Proia, R. L., A. d'Azzo, and E. F. Neufeld. 1983. Association of $\alpha$ and $\beta$ subunits during biosynthesis of $\beta$-hexosaminidase in cultured human fibroblasts. J. Biol. Chem. 259:3350-3354.

22. Yu, R. K., T. Itoh, H. C. Yohe, and L. J. Macala. 1983. Characterization of some minor gangliosides in Tay-Sachs brains. Brain Res. 275:47-52.

23. Johnson, W. G., L. M. Glaubiger, and G. H. Thomas. 1981. A sensitive and specific screening test for the mucolipidoses-HPTLC of urinary oligosaccharides. Neurology. 31(Pt. 2):87.

24. Rattazzi, M. D., A. M. Appel, and H. J. Baker. 1982. Enzyme replacement in feline $G_{M 2}$ gangliosidosis: catabolic effects of human $\beta$ hexosaminidase-A. In Animal Models of Inherited Metabolic Diseases. R. J. Desnick, D. F. Patterson, and D. G. Scarpelli, editors. Alan R. Liss, Inc., NY. 213-220.

25. Johnson, W. G., R. J. Desnick, D. M. Long, H. L. Sharp, W. Krivit, B. Brady, and R. O. Brady. 1973. Intravenous injection of purified hexosaminidase-A into a patient with Tay-Sachs disease. In Enzyme Therapy in Genetic Disease. R. L. Desnick, R. W. Bernlohr, and W. Krivit, editors. Williams and Wilkins, Baltimore. 120-124.

26. von Specht, B. U., B. Geiger, R. Arnon, J. Passwell, G. Keren, B. Goldman, and B. Pacleh. 1979. Enzyme replacement in Tay-Sachs disease. Neurology. 29:848-854.

27. Neuwelt, E. A., and E. P. Frenkel. 1980. Is there a therapeutic role for blood-brain barrier disruption? Ann. Intern. Med. 93:137-139.

28. Neuwelt, E. A., and S. I. Rapoport. 1984. Modification of the blood-brain barrier in the chemotherapy of malignant brain tumors. Fed. Proc. 43:214-219.

29. Neuwelt, E. A., D. E. Baker, M. A. Pagel, and N. K. Blank. 1984. The cerebrovascular permeability and delivery of gentamicin to normal and experimental brain abscess in rats. J. Neurosurg. 61:430439.

30. Neuwelt, E. A., J. A. Barranger, R. O. Brady, M. Pagel, F. S. Furbish, J. M. Quirk, G. E. Mook, and E. P. Frenkel. 1981. Delivery of hexosaminidase-A to the cerebrum after osmotic modification of the blood-brain barrier. Proc. Natl. Acad. Sci. USA. 78:5838-5841.

31. Neuwelt, E. A., J. A. Barranger, M. A. Pagel, R. O. Brady, and E. P. Frenkel. 1984. Delivery of active hexosaminidase-A across the blood brain barrier in rats. Neurology. 34:1012-1019.

32. Hickman, S., L. J. Shapiro, and E. F. Neufeld. 1974. A recognition marker required for uptake of lysosomal enzyme by cultured fibroblasts. Biochem. Biophys. Res. Commun. 57:55-61.

33. Kusiak, J. W., J. H. Toney, J. M. Quirk, and R. O. Brady. 1979. Specific binding of ${ }^{125}$-I-labeled $\beta$-hexosaminidase-A to rat brain synaptosomes. Proc. Natl. Acad. Sci. USA. 76:982-985.

34. Brooks, S. E., L. M. Hoffman, M. Adachi, D. Amsterdam, and L. Schneck. 1980. Enzyme replacement treatment for Tay-Sachs disease brain cells in culture utilizing conconavalin-A mediated hexosaminidase-A uptake: biochemical and morphological evidence of $\mathrm{G}_{\mathrm{M} 2}$ mobilization. Acta Neuropathol. 50:9-17.

35. O'Dowd, B. F., F. Quan, H. F. Williard, A. M. Lamhonwah, R. G. Korneluk, Z. A. Lowden, R. A. Gravel, and D. J. Mahuran. Isolation of cDNA clones coding for the $\beta$ subunit of human $\beta$ hexosaminidase. Proc. Natl. Acad. Sci. USA. 82:1184-1188. 